\title{
KATA SAPAAN BAHASA ACEH DIALEK ACEH BESAR (TINJAUAN SOSIOLINGUISTIK)
}

\author{
oleh \\ Ismawirna, Erfinawati ${ }^{*}$ \& Ramanda Rizka \\ *Dosen Program Studi Pendidikan Bahasa Indonesia, FKIP Universitas Serambi Mekkah \\ Surel: watierfina6@gmail.com
}

\begin{abstract}
ABSTRAK
Penelitian ini berjudul "Kata Sapaan Bahasa Aceh Dialek Aceh Besar (Tinjauan Sosiolingustik)". Rumusan masalah dalam penelitian ini adalah Kata sapaan apa yang digunakan dalam masyarakat dialek Aceh Besar dan Faktor apakah yang mempengaruhi penggunaan kata Sapaan dalam masyarakat dialek Aceh Besar. Tujuan penelitian ini adalah untuk mendeskripsikan penggunaan kata sapaan yang digunakan masyarakat dialek Aceh Besar dan untuk memperoleh data dan informasi terhadap kata sapaan yang digunakan masyarakat dialek Aceh Besar. Metode penelitian yang digunakan dalam penelitian ini adalah kualitatif yang bersifat deskriptif. Sumber data dalam penelitian ini adalah tokoh masyarakat yang ada di Kabupaten Aceh Besar. Peneliti hanya meneliti kata sapaan dalam bahasa Aceh dialek Aceh Besar yang terdapat di Kecamatan Indrapuri, Desa Reukih Dayah, Kecamatan Ingin Jaya Desa Dham Ceukok, dan Kecamatan Kuta Baro Desa Lambaro Bileu. Pengumpulan data dilakukan dengan melalui observasi, wawancara, dan rekaman. Teknik analisis data dalam penelitian ini yaitu reduksi data, penyajian data, dan penarikan kesimpulan. Hasil penelitian ini adalah pemakaian kata sapaan dan faktor perbedaan usia, jenis kelamin, dan status sosial sangat berpengaruh dalam pemakaian sapaan di Kecamatan Indrapuri Desa Reukih Dayah, Kecamatan Ingin Jaya Desa Dham Ceukok, dan Kecamatan Kuta Baro Desa Lambaro Bileu. Simpulan penelitian ini adalah kata sapaan yang digunakan dalam masyarakat dialek Aceh Besar yang meliputi sapaan umum, agama, jabatan, dan adat sesuai dangan tujuan dan ruang lingkup penelitian. Faktor-faktor yang mempengaruhi pemilihan sapaan yang digunakan masyarakat bahasa Aceh dialek Aceh Besar (Tinjauan Sosiolinguistik) adalah faktor usia, jenis kelamin, dan status sosial.
\end{abstract}

Kata Kunci: Kata Sapaan, bahasa Aceh, dialek Aceh Besar

\section{PENDAHULUAN}

Fungsi bahasa Aceh sebagai alat komunikasi utama dalam masyarakat pemakai bahasa Aceh. Bahasa ini digunakan sebagai aspek kehidupan dan penghidupan masyarakat berbahasa ibu. Bahasa Aceh ini berfungsi sebagai alat komunikasi dalam keluarga, pergaulan sehari-hari, keagamaan, peradatan, pendidikan dan pengajaran.

Kata sapaan, menurut Kamus Besar Bahasa Indonesia berarti 'kata ajakan untuk bercakap, teguran, ucapan, yang dalam 
konteks linguistik berarti 'kata atau frasa untuk saling merujuk dalam pembicaraan yang berbeda-beda menurut sifat hubungan diantara pembicara itu, seperti Anda, Ibu, Saudara (Aslinda, 2000:3).

Tutur sapaan adalah salah satu unsur bahasa yang selalu dipakai dalam peristiwa komunikasi yang mengikut kesantunan dalam kehidupan bermasyarakat. Adat bersopan santun menentukan bagaimana seseorang sepatutnya bersikap terhadap orang lain dalam hubungan berkerabat dan tak berkerabat (Koentjaraningrat, 1992:146).

Aceh Besar dalam istilah Aceh disebut Aceh Rayeuk. Penyebutan Aceh Rayeuk sebagai Aceh yang sebenarnya karena daerah inilah pada mulanya menjadi inti Kerajaan Aceh dan juga karena disitulah terletak ibukota kerajaaan yang bernama Bandar Aceh atau Bandar Aceh Darussalam. Untuk nama Aceh Rayeuk ada juga yang menamakan dengan sebutan Aceh Lhee Sagoe (Aceh Tiga Sagi).

Rumusan masalah dalam penelitian ini adalah Kata sapaan apa yang digunakan dalam masyarakat dialek Aceh Besar dan Faktor apakah yang mempengaruhi penggunaan kata Sapaan dalam masyarakat dialek Aceh Besar.

Adapun tujuan dari penelitian ini adalah untuk mendeskripsikan penggunaan kata sapaan yang digunakan masyarakat dan untuk memperoleh data dan informasi terhadap kata sapaan yang digunakan masyarakat dialek Aceh Besar.

Beberapa manfaat dari penelitian ini adalah dapat menjadi bahan masukan bagi masyarakat yang menggunakan sapaan dalam tuturan, sehingga dapat meningkatkan dan memeliharanya sebagaimana mestinya dan bagi peneliti lain agar bisa menjadi pedoman atau panduan dalam penelitian serupa lebih lanjut. Penelitian ini akan sangat berguna bagi pengkajian linguistik Nusantara dan dalam bidang antropologi, temuan penelitian ini diharapkan dapat menjadi pengenalan karakter budaya suatu masyarakat, pengaruh budaya terhadap bahasa.

\section{LANDASAN TEORI}

Kata sapaan adalah kata yang digunakan untuk menyapa orang yang diajak berbicara. Kridalaksana (dalam Aslinda 2000:3), "semua bahasa mempunyai bahasa tutur sapaan, yakni sistem yang mempertautkan seperangkat kata-kata atau ungkapan yang dipakai untuk menyapa para pelaku dalam suatu peristiwa".

Dalam kehidupan berbahasa terlihat beberpa pihak yang memiliki kondisi yang berbeda yang menyebabkan adanya perilaku bahasa yang bermacam-macam. Kata sapaan merupaka kata yang digunakan untuk menyapa orang. Dalam menyapa, orang atau si penyapa selalu memperhatikan beberapa hal, diantaranya kepada siapa, situasi bagaimana dan dimana (Syafyahya dkk, 2000:134).

Syafyahya (dalam Rizal, 2009:9), membagi jenis-jenis kata sapaan dapat diklasifikasikan sebagai berikut:

(1) Kata-kata sapaan ini tidak mempunyai pembendaharaan kata sendiri, tetapi menggunakan kata-kata dari pebendaharaan kata nama diridan kata nama perkerabatan.

(2) Begitu juga dengan nama perkerabatan, semua bentuk utuhnya dan bentuk singkatnya dapat dipakai hanya perlu diperhatikan, tidak semua kata perkerabatan ada bentuk singkatnya.

(3) Kata sapaan bidang agama ialah kata sapaan yang digunakan untuk menyapa orang yang mendalami dan bekerja dibidang agama.

(4) Kata sapaan bidang adat adalah kata sapaan yang digunakan untuk menyapa orang yang memangku jabatan dalam jabatan. 
(5) Kata sapaan umum digunakan untuk menyapa orang lain.

(6) Sapaan kata ganti digunakan untuk menyapa orang pertama, kedua, atau ketiga, baik orang pertama, kedua, maupun ketiga, ada tunggal pula yang jamak.

(7) Kata sapaan nama diri dengan fungsi sebagai kata sapaan dapat digunakan terhadap orang yang sudah akrab serta berusia sebaya atau jauh lebih muda.

Kata sapaan yang digunakan dalam Bahasa Indonesia pembicara untuk menyapa lawan bicaranya cukup bervarisai. Meskipun demikian, jenis kata sapaan yang nampaknya paling banyak digunakan adalah istilah kekerabatan (Kridalaksana, 1982: 193). Pemilihan suatu bentuk kata sapaan dipengaruhi oleh dua faktor, yakni status dan fungsi. Status dapat diartikan sebagai posisi sosial lawan bicara terhadap pembicara. Status tersebut dapat pula diartikan sebagai usia.

Hubungan antara yang menyapa dengan disapanya itu dapat berupa hubungan kerabat atau hubungan bukan kerabat. Jenis hubungan itu menentukan pilihan kata sapaan yang digunakan, baik sapaan itu berkaitan dengan adat agama dan status maupun berkaitan dengan umur dengan jenis kelamin (Sulaiman, dkk 1990:7).

"Sapaan umum merupakan sapaan yang berlaku dalam masyarakat Aceh dalam hubungan tidak resmi dalam hubungan dengan kerabat maupun diluar kekerabatan yang tidak dikaitkan dengan kedudukan seseorang baik dalam adat, agama, maupun dalam jabatan resmi" (Sulaiman, dkk 1990:13).

Sulaiman, dkk (1990:38) mengatakan bahwa "sapaan agama dalam masyarakat Aceh berkaitan dengan dikenal atau idak dikenalnya seseorang yang disapa.

Sapaan Jabatan adalah sapaan yang berkaitan dengan jabatan yang dipangku oleh seseorang. Sapaan terhadap orang tersebut biasanya disesuaikan dengan jabatan yang di pangkunya itu (Sulaiman, dkk 1990:49).

Sapaan adat adalah kata sapaan yang berupa gelar. Gelar dalam masyarakat Aceh pada umumnya didasarkan atas keturunan seseorang, baik keturunan bangsawan maupun keturunan Arab. (Sulaiman, dkk 1990:59).

Dialek merupakan sub bahasa. Sebagai sub bahasa, dialek memiliki ciri-ciri yang dimiliki bahasa. Untuk menentukan apakah evidensi yang dituturkan suatu masyarakat di daerah tertentu adalah bahasa ataukah dialek (Zulaeha, 2010:31).

Ayatrohaedi (1983:2) menyatakan bahwa ada dua ciri lain yang memiliki dialek yaitu:

(1) Dialek ialah seperangkat bentuk ujaran setempat yang berbeda-beda yang memiliki ciri-ciri umum dan masingmasing lebih mirip sesamanya dibandingkan dengan bentuk ujaran lain dari bahasa yang sama.

(2) Dialek itu tidak harus mengambil semua bentuk ujaran dari sebuah bahasa.

Dialek yang satu berbeda dengan dialek yang lain karena masing-masing memiliki kekhasan yang bersifat lingual. Kekhasan inilah yang menjadi pembeda bagi dialekdialek tersebut (Ayatrohaedi, 1983:3-5).

Dialek geografi merupakan cabang lingustik yang bertujuan mengkaji semua gejala kebahasaan secara cermat yang disajikan berdasarkan peta bahasa yang ada. Dialek sosial adalah ragam bahasa yang dipergunakan oleh kelompok tertentu yang membedakannya dari kelompok masyarakat lainnya. Kelompok itu terdiri atas pekerjaan, usia, kegiatan, jenis kelamin, pendidikan, dan sebagainya. Dalam perkembangannya, dialek sosial dalam kajian dialektologi mengacu pada dialek yang dituturkan oleh penutur di daerah 
tertentu berdasarkan variabel sosial penuturnya. Dialek ini dimungkinkan mengalami perbedaan antara penutur dari variabel sosial tertentu dengan variabel sosial yang lain meskipun mereka berada dan berasal di daerah yang sama (Zulaeha, 2010:29).

Abdul Chear (2003:5) menyatakan "Sosiolinguistik adalah hubungan antara bahasa dengan faktor-faktor yang berlaku dalam masyarakat; tepatnya berdasarkan status, fungsi, penilaian yang diberikan masyarakat terhadap bahasa itu". Sosioliguistik ini pernah dilakukan oleh William A. Stuart tahun 1962 yang dapatkita baca dalama artikelnya "An Outline of Linguistic Typology for Describing Multingualism".

Seperti yang kita ketahui bahasa dan masyarakat merupakan dua sisi mata uang yang tidak dapat dipisahkan, tidak mungkin ada masyarakat tanpa bahasa dan tidak mungkin pula ada bahasa tanpa masyarakat. Seiring dengan berkembangnya ilmu pengetahuan dan teknologi, maka bahasa pun mengalami perubahan yang sangat signifikan. Chaer (2004:15) berpendapat bahwa fungsi yang menjadi persoalan sosiolinguistik adalah dari segi penutur, pendengar, topik, kode, dan amanat pembicaraan. Jadi hubungan sosiolinguistik dengan masyarakat ini berkaitan erat terhapat variasi-variasi bahasa yang digunakan oleh masyarakat.

\section{METODE PENELITIAN}

Jenis penelitian yang dipakai dalam penyusunan skripsi ini adalah penelitian lapangan (field research) dan studi pustaka (library research), yaitu penelitian yang dilakukan dengan cara terjun langsung ke daerah objek penelitian guna memperoleh data yang berhubungan dengan kata sapaan dalam bahasa Aceh dialek Aceh Besar khususnya masyarakat di Kecamatan Indrapuri Desa Reukih Dayah, Kecamatan
Ingin Jaya Desa Dham Ceukok, dan Kecamatan Kuta Baro Desa Lambaro Bileu. Arikunto, (2005:234) Jenis penelitian yang digunakan adalah penelitian kualitatif yang bersifat deskriptif yaitu penelitian yang dimaksudkan untuk mengumpulkan informasi mengenai status suatu gejala yang ada, yaitu keadaan gejala menurut apa adanya pada saat penelitian dilakukan.

Sumber data dalam penelitian adalah tokoh masyarakat yang ada di Kabupaten Aceh Besar. Peneliti hanya meneliti kata sapaan dalam bahasa Aceh dialek Aceh Besar yang terdapat di Kecamatan Indrapuri Desa Reukih Dayah, Kecamatan Ingin Jaya Desa Dham Ceukok, dan Kecamatan Kuta Baro Desa lambaro Bileu. Sumber data diperoleh dari hasil wawancara tokoh masyarakat yang ada Kecamatan Ingin Jaya Desa Dham Ceukok, dan Kecamatan Kuta Baro Desa lambaro Bileu yang berupa kata atau kalimat yang direkam dari informan yang berbahasa ibu bahasa Aceh yang mengenai kata sapaan dalam bahasa Aceh dialek Aceh Besar yang mempunyai dialek yang berbeda.

Teknik pengumpulan data merupakan pekerjaan yang penting dalam meneliti (Arikunto, 2006:223). Tanpa mengetahui teknik pengumpulan data, maka peneliti tidak akan mendapatkan data yang memenuhi standar data yang ditetapkan (Sugiyono, 2008:224).

Teknik pengumpulan data adalah cara yang dilakukan untuk mengumpulkan data yang diperlukan dalam penelitian. Teknik pengumpulan data dilakukan sebagai berikut ini.

(1) Observasi

(2) Wawancara

(3) Rekaman

Sugiyono (2008:335) mengatakan bahwa analisis dalam penelitian merupakan cara berfikir yang berkaitan dengan pengujian secara sistematis. Data yang telah 
dikumpulkan harus dianalisis. Analisis data merupakan upaya mencari dan menata secara sistematika catatan hasil dari observasi, wawancara dan lainnya untuk meningkatkan pemahaman peneliti tentang kasus yang diteliti. Setelah data dikumpulkan lalu dianalisis guna mendapatkan data-data yang objektif dan relavan dengan topik pembahasan.

Analisis data dalam penelitian ini dilakukan melalui tiga kegiatan yang terjadi secara bersamaan yaitu reduksi data, penyajian data, dan penarikan kesimpulan (Sugiyono, 2015:246).

Penelitian ini teknik analisis data yang digunakan sebagai berikut:

(a) Klasifikasi data,

(b) Penyajian data,

(c) Kesimpulan.

\section{HASIL PENELITIAN DAN PEMBAHASAN}

Deskripsi data yang akan disajikan dari hasil penelitian ini adalah untuk memberikan gambaran umum mengenai data yang diperoleh. Data dalam penelitian ini berupa Kata Sapaan Bahasa Aceh Dialek Aceh Besar (Tinjauan Sosiolinguistik).

Data dalam penelitian ini dapat dikelompokkan dalam data kata sapaan yang digunakan dalam masyarakat dialek Aceh Besar yang meliputi:

(1) sapaan umum adalah kata sapaan yang digunakan untuk menyapa seseorang didalam dan diluar kerabat masyarakat Aceh yang tidak dikaitkan dalam fungsinya dalam adat, agama, dan jabatan resmi

(2) sapaan agama adalah sapaan yang berkaitan dengan dikenal atau idak dikenalnya seseorang yang disapa. Apabila yang disapa itu tidak dikenal identitasnya, tetapi dikenal sebagai orang Aceh dan dianggap telah dewasa, maka bentuk sapaan yang dipakai adalah bentuk sapaan teungku.
(3) sapaan jabatan adalah sapaan yang berkaitan dengan jabatan yang dipangku oleh seseorang.

(4) sapaan adat adalah kata sapaan yang berupa gelar.

Analisis data yang dipaparkan dalam penelitian ini meliputi analisis data kata sapaan dalam bahasa Aceh dialek Aceh Besar khususnya masyarakat di Kecamatan Indrapuri Desa Reukih Dayah, Kecamatan Ingin Jaya Desa Dham Ceukok, dan Kecamatan Kuta Baro Desa Lambaro Bileu. Analisis data penelitian meliputi data (1) sapaan umum, (2) sapaan agama, (3) sapaan jabatan, (4) dan sapaan adat.

Pembahasan dalam penelitian ini adalah Kata Sapaan Bahasa Aceh Dialek Aceh Besar (Tinjauan Sosiolinguistik). Pembahasan ini dilakukan sebagaimana pengelompokkan kata sapaan yang digunakan dalam masyarakat dialek Aceh Besar. Berikut pembahasan Kata Sapaan Bahasa Aceh Dialek Aceh Besar (Tinjauan Sosiolinguistik).

Pemakaian sapaan kekerabatan di Kecamatan Indrapuri Desa Reukih Dayah, Kecamatan Ingin Jaya Desa Dham Ceukok, dan Kecamatan Kuta Baro Desa Lambaro Bileu terjadi bukan karena kerabat melainkan memiliki status yang lebih tinggi, sehingga sapaan ini timbul karena untuk menghormati tersapa maka penyapa menggunakan sapaan kekerabatan. Dengan demikian, kekerabatan di Kecamatan Indrapuri Desa Reukih Dayah, Kecamatan Ingin Jaya Desa Dham Ceukok, dan Kecamatan Kuta Baro Desa Lambaro Bileu dalam masyarakat Aceh adalah semua kerabat ayah dan ibu serta kerabat atas dasar perkawinan. Untuk lebih jelas berikut ini dikemukakan beberapa macam kata sapaan umum bahasa Aceh dialek Aceh Besar Tinjauan Sosiolinguistik) yang digunakan di daerah penelitian.

(1) Kata Sapaan untuk Menyapa Ayah Kandung 
Daerah penelitian Kecamatan Ingin Jaya Desa Dham Ceukok. untuk menyapa orang tua kandung sendiri digunakan kata sapaan Mak dan Ayah. Kata sapaan Bunda dan Waled, kata sapaan tersebut digunakan di Kecamatan Kuta Baro Desa Lambaro Bileu. Sedangkan di Kecamatan Indrapuri Desa Reukih Dayah kata sapan yang digunakan Mamak dan Ayah. Kata tersebut digunakan sebagai akibat pengariki agama Islam di Aceh. Pada umumnya kata sapaan itu dipakai untuk menunjukkan bahwa orang yang disapa itu berilmu pengetahuan agama dan digunakan oleh samua kelompok umur. Kata sapaan $A b u$ dan $A b a$, secara khusus menunjukkan bahwa orang yang disapa berasal dari kelompok ulama. Kata sapaan digunakan untuk menyapa ayah kandung oleh setiap strata sosial dalam masyarakat Aceh adalah seperti tercantum pada tabel di atas. Ketiga daerah penelitian Kecamatan Indrapuri Desa Reukih Dayah, Kecamatan Ingin Jaya Desa Dham Ceukok, dan Kecamatan Kuta Baro Desa Lambaro Bileu menggunakan kata sapaan yang berbeda.

(2) Sapaan untuk Orang Lain yang Sebaya

Bentuk sapaan untuk menyapa orang yang sebaya menggunakan dialek yang sama pemakaiannya di daerah penelitian di Kecamatan Indrapuri Desa Reukih Dayah, Kecamatan Ingin Jaya Desa Dham Ceukok, dan Kecamatan Kuta Baro Desa Lambaro Bileu yaitu dengan sebutan nama. Hal tersebut disebabkan oleh golongan masyarakat yang disapanya.

(3) Kata Sapaan Untuk Menyapa Kakak Lelaki Ayah Kandung

Bentuk sapaan untuk adik laki-laki ayah seperti tampak dalam tabel di atas bervariasi antara daerah satu dengan daerah lainnya dan digunakan oleh golongan masyarakat sebagai tercantum dalam tabel diatas. Kecamatan Kuta Baro Desa Lambaro Bileu sapaan yang digunakan sapaan Yahwa dan Yah Bang. Di Kecamatan Ingin Jaya
Desa Dham Ceukok sapaan yang digunakan untuk adik laki-laki ayah dengan sapaan Yah Bang, Yah Dun, Yah Cut dan Yah Bit. Sedangkan di Kecamatan Indrapuri Desa Reukih Dayah sapaan yang digunakan untuk adik laki-laki ayah dengan sapaan Paman.

(4) Kata Sapaan Anak-Anak Kepada Bapak/Ibu Di rumah

Daerah penelitian ini, Kecamatan Kuta Baro Desa Lambaro Bileu, Kecamatan Ingin Jaya Desa Dham Ceuko, untuk menyapa orang tua kandung sendiri digunakan kata sapaan Mak dan Ayah. Sedangkan Kecamatan Indrapuri Desa Reukih Dayah Kata sapaan Abi dan Ummi kata sapaan tersebut digunakan oleh anak Tengku. Pada umumnya kata sapaan itu dipakai untuk menunjukkan bahwa orang yang disapa itu berilmu pengetahuan agama dan digunakan oleh samua kelompok umur. Kata sapaan digunakan anak-anak untuk menyapa ayah kandung oleh setiap strata sosial dalam masyarakat Aceh adalah seperti tercantum pada tabel di atas.

(5) Kata Sapaan untuk Bertanya Kepada Orang yang Seumuran Bapak/Ibu Dari Mana Pulang, dan Dimana Rumahnya.

Kata sapaan untuk bertanya kepada orang yang seumuran bapak/ibu dari mana pulang, dan dimana rumahnya, memiliki perbadaan dialek. Di Kecamatan Indrapuri Desa Reukih Dayah menggunakan Panee ban neujak? Dipat rumoh dron?, Kecamatan Ingin Jaya Desa Dham Ceukok menggunakan Droen dari pat? Pat rumoh droen?, dan Kecamatan Kuta Baro Desa Lambaro Bileu menggunakan Panee neu woe, pat rumoh dron?

(6) Kata Sapaan Kepada Menantu Anda Baik Laki-Laki Maupun Wanita

Kata sapaan kepada menantu anda baik laki-laki maupun wanita digunakan sapaan yang sama pada daerah penelitian di Kecamatan Indrapuri Desa 
Reukih Dayah, Kecamatan Ingin Jaya Desa Dham Ceukok, dan Kecamatan Kuta Baro Desa Lambaro Bileu, yaitu dengan menyebut Nyak dan nama menantu itu sendiri.

(7) Kata Sapaan Untuk Menyebutkan Kepada Diri Anda Sendiri

Sapaan nama diri biasanya digunakan oleh orang yang sudah akrab serta berusia sebaya atau jauh lebih muda. Daerah penelitian ini Kecamatan Kuta Baro Desa Lambaro Bileu, Kecamatan Ingin Jaya Desa Dham Ceukok, Kecamatan Indrapuri Desa Reukih Dayah menggunakan kata sapaan yang berbeda terhadap diri sendiri. Pemakaian bentuk sapaan lon dalam komunikasi sapa-menyapa masyarakat di Kecamatan Indrapuri Desa Reukih Dayah dan Kecamatan Ingin Jaya Desa Dham Ceukok seperti dikemukakan di atas adalah berdasarkan atas anggapan umum untuk sapaan nama diri. Kecamatan Kuta Baro Desa Lambaro Bileu bentuk sapaan $U$ Lon adalah untuk menyapa diri sendiri.

Sapaan agama dalam masyarakat Aceh berkaitan dengan dikenal atau tidak dikenalnya seseorang yang disapa. Apablla yang disapa itu tidak dikenal identitasnya, tetapi dikenal sebagai orang Aceh dan dianggap telah dewasa, maka bentuk sapaan yang dipakai adalah bentuk sapaan tengku. Bentuk sapaan ini berlaku secara umum diantara anggota masyarakat pemakai bahasa Aceh. Kata Sapaan untuk Guru Pengajian.

Pemakaian bentuk sapaan Tengku dan Ummi dalam komunikasi sapa-menyapa masyarakat di Kecamatan Indrapuri Desa Reukih Dayah seperti dikemukakan di atas adalah berdasarkan atas anggapan umum bahwa semua orang Aceh itu tergolong masyarakat yang taat melaksanakan agama Islam, kendatipun ia kurang atau tidak berilmu secara luas dalam bidang keagamaan. Dalam hal ini, pemakaian bentuk sapaan Tengku dalarn komunikasi masyarakat Aceh telah mengalarni pergeseran fungsi dalam sapaan gelar keagamaan dalam masyarakat Aceh. Kecamatan Kuta Baro Desa Lambaro Bileu bentuk sapaan Teungku, Ummi adalah gelar orang yang ahli atau berilmu dalam bidang agarna Islam atau yang lebih taat dari kebanyakan orang, atau menjabat jabatan yang berhubungan dengan agama seperti orang-orang suci, orang-orang yang telah menunaikan ibadah haji, guru agama, terutama penguasa kampung yang bertugas membina kehidupan beragama. Dalam penelitian Kecamatan Ingin Jaya Desa Dham Ceukok Kata sapaan untuk menyapa guru pengajian sebagian menggunakan kata Anda. Kata sapaan tersebut yang mempunyai makna guru pengajian untuk wanita.

(1) Kata Sapaan untuk Orang yang Ahli Dibidang Agama

Kata sapaan yang digunakan di Kecamatan Indrapuri Desa Reukih Dayah, Kecamatan Ingin Jaya Desa Dham Ceukok, Kecamatan Kuta Baro Desa Lambaro Bileu khusus untuk sapaan $A b u$ sapaan ini merupakan salah satu ciri yang menujukkan bahwa orang yang disapa itu ahli dalam bidang agama atau yang disapa itu adalah seorang ulama. Sedangkan di Kecamatan Indrapuri Desa Reukih Dayah sapaan untuk orang yang ahli dibidang agama dengan sapaan Pak Imam.

(2) Kata Sapaan Sebagai Istri Seorang Ulama Atau Orang yang Mengetahui Masalah Keagamaan

Sapaan sebagai istri seorang ulama atau orang yang mengetahui masalah keagamaan. Setiap daerah penelitian mempunyai dialek yang berbeda. Seperti di Kecamatan Indrapuri Desa Reukih Dayah, kata sapaan yang digunakan adalah Inoeng Tengku dan Ibu Pak Imam. Sedangkan Kecamatan Ingin Jaya Desa Dham Ceukok dan Kecamatan Kuta Baro Desa Lambaro Bileu menggunakan kata sapaan Ummi. 
(3) Kata Sapaan Sebagai Muazin dalam Kebiasaan Masyarakat Biasa

Daerah penelitian ini Kecamatan Kuta Baro Desa Lambaro Bileu, Kecamatan Ingin Jaya Desa Dham Ceukok, Kecamatan Indrapuri Desa Reukih Dayah menggunakan kata sapaan yang sama terhadap muazin. Sapaan muazin mengandung arti orang menyerukan atau memanggil orang lain untuk bersembahyang. Kata sapaan terhadap muazin ini digunakan kata bileue di semua tempat ymg dijadikan daerah penelitian. Kata sapaan Bileue dan Teungku Bileue berbeda dalam pemakaiannya.

(4) Kata Sapaan Kepada Orang yang Bertugas Menikahkan Orang Lain

Kata sapaan kepada orang yang bertugas menikahkan orang lain di daerah penelitian di Kecamatan Indrapuri Desa Reukih Dayah, Kecamatan Ingin Jaya Desa Dham Ceukok, dan Kecamatan Kuta Baro Desa Lambaro Bileu adalah sebagai berikut

Kata sapaan di atas digunakan kepada orang yang bertugas menikahkan orang lain. Di Kecamatan Kuta Baro Desa Lambaro Bileu dan Kecamatan Indrapuri Desa Reukih Dayah kata sapaan yang digunakan adalah Tengku Kadhi. Sedangkan Kecamatan Ingin Jaya Desa Dham Ceukok kata sapaan yang digunakan adalah Pak Kuaket. Kedua sapaan ini memiliki arti yang sama, namun penyebutannya saja yang berbeda, tergantung pada kebiasaan sebuah daerah. Namun pada dasarnya adalah orang yang bekerja untuk menikahkan orang disebuah tempat atau daerah di Aceh.

Kata sapaan adat dalam bahasa Aceh yang digunakan di daerah penelitian didasarkan pada gelar bangsawan keturunan Arab, dan gelar bagi orang biasa yang dikaitkan dalam bidang khusus keahliannya yang dilakukan dalam kehidupan seharihari. Termasuk pekerjaan yang berhubungan dengan tugas keagamaan.
(1) Kata Sapaan untuk Menyapa Seseorang yang Keturunan Bangsawan

Daerah Kecamatan Indrapuri Desa Reukih Dayah, Kecamatan Ingin Jaya Desa Dham Ceukok, dan Kecamatan Kuta Baro Desa lambaro Bileu, digunakan kata sapaan Ampon dan Teuku untuk menyapa bangsawan. Kata sapaan Ampon digunakan untuk menyapa bangsawan laki-laki. Di daerah Kecamatan Kuta Baro Desa lambaro Bileu kata sapaan Cut dan Pocut untuk menyapa istri dari golongan bangsawan. Sedangkan di daerah Indrapuri Desa Reukih Dayah, Kecamatan Ingin Jaya Desa Dham Ceukok, kata sapaan yang digunakan untuk menyapa istri dari golongan bangsawan dengan sapaan Cut dan Cut Nyak.

Sapaan Jabatan adalah sapaan yang berkaitan dengan jabatan yang dipangku oleh seseorang. Sapaan terhadap orang tersebut biasanya disesuaikan dengan jabatan yang di pangkunya itu.

(1) Kata Sapaan Kepada yang Lebih Muda Tetapi Ia Berpendidikan Lebih Tinggi

Sapaan di atas digunakan untuk menyapa kepada yang lebih muda tetapi ia berpendidikan lebih tinggi. Pada daerah penelitian Kuta Baro Desa Lambaro Bileu, menggunakan kata sapaan Gata. Kemudian pada Kecamatan Ingin Jaya Desa Dham Ceukok, kata sapaan kepada yang lebih muda tetapi ia berpendidikan lebih tinggi menggunakan kata Adek. Selanjutnya pada Kecamatan Indrapuri Desa Reukih Dayah, kata sapaan kepada yang lebih muda tetapi ia berpendidikan lebih tinggi menggunakan kata Kanda.

(2) Kata Sapaan untuk Kepala Desa

Kata sapaan keuchik digunakan oleh masyarakat di Kecamatan Indrapuri Desa Reukih Dayah, Kecamatan Ingin Jaya Desa Dham Ceukok, dan Kecamatan Kuta Baro Desa Lambaro Bileu.

Berkomunikasi, dalam kehidupan sehari-hari biasanya menggunakan sapaan untuk mengawali sebuah komunikasi atau 
pembicaraan, Sapaan yang digunakan berbeda-beda pula sesuai dengan kebutuhan dalam berkomunikasi, dengan perbedaanperbedaan ini maka akan timbul variasi sapaan.

Seperti halnya di Kecamatan Indrapuri Desa Reukih Dayah, Kecamatan Ingin Jaya Desa Dham Ceukok, dan Kecamatan Kuta Baro Desa Lambaro Bileu juga bervariasi. Pemilihan kata sapaan ini dipengaruhi oleh beberapa faktor yang melatarbelakangi seperti 1) usia, 2) jenis kelamin, dan 3) satatus sosial. Faktor-faktor yang melatarbelakangi variasi sapaan dapat dilihat dibawah ini.

Usia merupakan salah satu faktor yang mempengaruhi variasi penggunaan sapaan, karena sebelum menyapa sipenyapa harus mempertimbangkan terlebih dahulu siapa yang akan disapa. Sipenyapa akan mempertimbangkan terlebih dahulu usia tersapa, apakah masih anak-anak, remaja, sebaya, atau orang dewasa. Perhitungan tersebut dilakukan untuk menghindari kesalahpahaman atau salah menyapa, dengan demikian penyapa dapat memilih kata sapaaan yang tepat untuk menyapa lawan bicaranya

Kata sapaan di Kecamatan Indrapuri Desa Reukih Dayah, Kecamatan Ingin Jaya Desa Dham Ceukok, dan Kecamatan Kuta Baro Desa lambaro Bileu juga tidak biasa lepas dari faktor di atas, karena penduduk di Kecamatan Indrapuri Desa Reukih Dayah, Kecamatan Ingin Jaya Desa Dham Ceukok, dan Kecamatan Kuta Baro Desa lambaro Bileu Sapaan yang digunakan tergantung usia yang disapa.

Perbedaan jenis kelamin juga merupakan faktor yang menentukan pemilihan sapaan yang akan digunakan penyapa untuk menyapa lawan bicaranya. Faktor jenis kelamin ini dibedakan menjadi dua, untuk seseorang yang jenis kelaminnya laki-laki dan jenis kelamin perempuan, begitu juga di Kecamatan Indrapuri Desa
Reukih Dayah, Kecamatan Ingin Jaya Desa Dham Ceukok, dan Kecamatan Kuta Baro Desa lambaro Bileu faktor jenis kelamin dibedakan menjadi dua. Untuk menyapa seseorang yang berjenis kelaminnya lakilaki masyarakat menggunakan sapaan Ayah, Yahwa, Tengku, Ampon, Pak Kuaket, dan Pak Imam. Untuk menyapa yang berjenis kelamin perempuan biasanya menggunakan sapaan Mak, Ummi, dan Cut Nyak.

sapaan mak merupakan sapaan yang digunakan penyapa untuk menyapa orangtua kandung yang berjenis kelamin perempuan karena usia penyapa dan tersapa orangtua kandung tersapa maka penyapa menggunaan sapaan Mak.

Ummi dan Inoeng Tengku merupakan sapaan yang digunakan penyapa untuk menyapa istri seorang ulama atau orang yang mengetahui masalah keagamaan seseorang yang berjenis kelamin perempuan dan keduanya sudah saling mengenal, karena usia penyapa dengan tersapa lebih tua dari penyapa maka penyapa menggunakan sapaan Ummi dan Inoeng Tengku.

Sapaan Yahwa digunakan karena tersapa mempunyai usia yang lebih tua dari penyapa, maka penyapa menggunakan sapaan Yahwa. Sapaan Yahwa sendiri digunakan karena keduanya sudah saling mengenal dan untuk menghormati tersapa maka penyapa menggunakan sapaan Yahwa.

Status sosial juga merupakan faktor yang menentukan dalam kata sapaan, karena status sosial merupakan salah satu yang hubungannya dengan kedudukan seseorang.

Karena status sosial yang disandangnya berbeda maka orang yang berpendidikan lebih tinggi menyapa dengan menggunakan sapaan Kanda dan Gata. Selain sapaan Kanda pada kalimat di atas terdapat kata sapaan lain yaitu Adek, sapaan Adek ini digunakan pelanggan untuk menyapa orang yang lebih muda tersebut. 
Berdasarkan hasil penelitian di atas dapat disimpulkan bahwa pemakaian kata sapaan dengan faktor perbedaan usia, jenis kelamin, dan status sosial sangat berpengaruh dalam pemakaian sapaan di Kecamatan Indrapuri Desa Reukih Dayah, Kecamatan Ingin Jaya Desa Dham Ceukok, dan Kecamatan Kuta Baro Desa lambaro Bileu.

\section{PENUTUP}

Berdasarkan hasil analisis dan pembahasan Kata Sapaan Bahasa Aceh Dialek Aceh Besar (Tinjauan Sosiolinguistik), maka penulis dapat menyimpulkan sebagai berikut:

(1) Kata sapaan yang digunakan dalam masyarakat dialek Aceh Besar yang meliputi: sapaan (a) umum, (b) agama, (c) jabatan dan, (d) adat sesuai dangan tujuan dan ruang lingkup penelitian.

(2) Faktor-faktor yang mempengaruhi pemilihan sapaan yang digunakan masyarakat Bahasa Aceh Dialek Aceh Besar (Tinjauan Sosiolinguistik) adalah faktor usia, jenis kelamin, dan status sosial.

Berdasarkan penelitian, pembahasan, dan kesimpulan tentang Kata Sapaan Bahasa Aceh Dialek Aceh Besar (Tinjauan Sosiolinguistik), dapat dikemukakan beberapa saran yang berkaitan dengan penelitian ini. saran yang dapat diberikan kepada pembaca sebagai berikut ini.

(1) Masyarakat dalam aktivitas berkomunikasi sering melakukan kesalahan, khususnya dalam kegiatan sapa-menyapa. Untuk itu, dari hasil analisis data yang sudah dibahas di atas, diharapkan masyarakat lebih memahami dan tidak ragu-ragu untuk menggunakan kata sapaan. Hal ini dikarenaka pemakaian sapaan yang tepat dan benar merupakan wujud penghormatan dan penghargaan kepada mitra tutur atau lawan tutur.

(2) Penelitian ini telah dapat menjangkau dan menjaring secara keseluruhan bentuk-bentuk kata sapaan yang terdapat di Kecamatan Indrapuri Desa Reukih Dayah, Kecamatan Ingin Jaya Desa Dham Ceukok, dan Kecamatan Kuta Baro Desa Lambaro Bileu. Hasil penelitian ini diharapkan dapat dijadikan sebagai bahan acuan untuk penelitian selanjutnya terutama yang berhubungan dengan kata sapaan.

\section{DAFTAR PUSTAKA}

Alwasilah, Chaedar.1985. Dialektologi Bahasa. Bandung: Angkasa.

Arikunto, Suharsimi. 2006. Prosedur Penelitian Suatu Pendekatan Praktis. Jakarta:Rineka Cipta.

2005. Prosedur Penelitian Suatu Pendekatan Praktis. Jakarta:Rineka Cipta.

Aslinda. 2003. Kata Sapaan Bahasa dalam Interaksi Linguistik. Jakarta: Rineka Cipta.

2000. Kata Sapaan Bahasa dalam Interaksi Linguistik. Jakarta: Rineka Cipta.

Ayatrohaedi, 1983. Dialektologi Sebuah Pengantar. Jakarta: Pusat Pembinaan dan Pengembangan Bahasa Departemen Pendidikan dan Kebudayaan.

Chear, Abdul. 2006. Tata Bahasa Praktis Bahasa Indonesia. Jakarta: Rineka Cipta. 
2004. Sosiolinguistik Perkenalan Awal Jakarta: Rineka Cipta.

2003. Sosioliguistik Hubungan Antara Bahasa. Jakarta: Rineka Cipta.

Kridalaksana, Harimurti. 1982. Kamus Lingustik. Jakarta: Gramedia.

Koentjaraningrat.1992. Beberapa Pokok Antropologi Sosial. Jakarta: Dian Rakyat

Sugiyono. 2015. Metode Penelitian Pendidikan (pendekatan kuantitatif, kualitatif dan $R \& D$ ). Bandung: Alfabeta.

2008. Metode Penelitian Pendidikan. Bandung: Alfabeta.

Sugono, Deny. 2007.Buku Praktis Bahasa Indonesia. Jakarta: Departemen Pendidikan Nasional.
Sulaiman, Budiman. 1990. Sistem Sapaan dalam Bahasa Aceh. Jakarta: Pusat Pembinaan dan Pengembangan Bahasa Departemen Pendidikan dan Kebudayaan.

Syafyahya. 2009. Jenis-jenis Kata Sapaan. Jakarta: PT Raja GrafindoPersada.

Syafyahya, Leni dkk. 2000. Kata Sapaan Bahasa Minang Kabau Di Kabupaten Agam. Jakarta: Proyek Pembinaan Bahasa dan Sastra Indonesia Dan Daerah.

Zulaeha, Ida. 2010. Dialektologi (Dialek Geografi dan Dialek Sosial). Yogyakarta: Graha Ilmu. 